\title{
IMPLEMENTASI ALGORITMA BELLMAND FORD UNTUK MENJEMPUT PASIEN MENGUNAKAN MOBIL AMBULANCE DENGN LOCATION BASED SERVICE BERBASIS ANDORID STUDIO (Studi Kasus: Rsud Linggajati)
}

\author{
Lukman Pirmansah $^{1}$, Dadang Hamdani ${ }^{2}$, Yati Nurhayati ${ }^{3}$ \\ SMK Pertiwi Cilimus ${ }^{1}$, FKOM UNIKU ${ }^{2,3}$ \\ E-mail :pirmansahlukman@gmail.com,...,yati.nurhayati@uniku.ac.id
}

\begin{abstract}
Abstrak
Ambulance berperan penting dalam penanganan pasien gawat darurat yang membutuhkan kecepatan dalam penanganan pasien. Namun demikian, karena kondisi lalu lintas dijalan raya ambulance seringkali mengalami keterlambatan kedatangan maupun keterlambatan dalam membawa pasien kerumah sakit. Maka dari itu, tujuan dari penelitian ini adalah untuk membuat aplikasi yang dapat memudahkan supir mobil ambulance untuk menemukan rute terpendek dari titik asal ke titik tujuan. Metode pengembangan perangkat lunak yang digunakan adalah Rational Unified Proccess (RUP) yang memiliki 4 tahapan : Inception, Elaboration, Construction, dan Transition. Algortima Bellmand ford merupakan algortima pencarian rute yang dapat menemukan rute terpendek dari titik awal (rumah sakit) sampai ke titik tujuan dengan cepat, yang merupakan pencarian rute terpendek dengan memperhitungkan semua rute. Aplikasi ini dibangun dengan menggunakan bahasa pemograman Android Studio untuk editor yang dimana bisa diakses oleh supir ambulance, serta admin melakukan pengolahan data titik titik tujuan dengan PHP, database MYSQL dan notepad++ untuk editor. Aplikasi ini telah diuji dengan menggunakan whitebox dan blacbox, hasil akhirnya aplikasi ini dapat membantu supir ambulance dalam menemukan rute terpendek ke titik tujuan sehingga dapat lebih cepat dalam menjemput dan menangani pasien yang membutuhkan pertolongan yang harus segera dibawa ke rumah sakit
\end{abstract}

Kata kunci : Rumah sakit, supir ambulance, pasien, algoritma Bellmand Ford, rute terpendek.

\begin{abstract}
Ambulance plays a vital role in in the emergency of patients that require the speed of care. Nevertheless, because of the traffic conditions, the ambulance has often been delayed in carrying the patient to the hospital. Therefore, the purpose of this study is to make an application that can facilitate an ambulance to find the shortest route to the destination. Software development method that is used is Rational Unified Process (RUP) that has 4 steps : Inception, Elaboration, Construction and Transition. Bellmand ford algorithm is a searching algorithm that can find the shortest route from the starting point (hospital) to the destination quickly. It is a short route searching by calculating all routes. The application is built using Android Studio as an editor to be accessed by an ambulance driver and PHP Programming for admin to process a data of destination point, MySQL as database and notepad++ for editor. This application has been tested by using the whitebox and blacbox, the outcome of this application can help the ambulance driver to find the shortest route to the point where it can be faster to pick up and deal with a patient who needs help to get to the hospital.
\end{abstract}

Keyword : Hospital, ambulance driver, patient, Bellmand Ford algorithm, shortest route

\section{PENDAhuluan}

Dewasa ini perkembangan teknologi informasi sangat pesat. Sehubungan dengan keadaan tersebut hampir seluruh aspek kehidupan memanfaatkan kecanggihan teknologi dengan tujuan agar lebih mudah 
JURNAL BUFFER INFORMATIKA

Volume 5 Nomor 2, Oktober 2019

dan bahkan lebih cepat untuk menjalankan suatu aktivitas. Salah satu hal yang membutuhkan pengolahan informasi dengan menggunakan teknologi saat ini adalah pencapaiaan suatu tempat dengan waktu yang secepat mungkin. Dalam hal ini, ambulance adalah salah satu kendaraan yang membutuhkan suatu inovasi yang dapat mengoptimalkan cara kerja dan fungsi ambulan sebagai mana mestinya.

Kecelakaan pada suatu lokasi tertentu sering kali terjadi. Pada insiden seperti ini tentunya membutuhkan pertolongan pertama secepat mungkin. Seperti halnya membutuhkan mobil ambulance untuk mengangkut korban kecelakaan tersebut agar dibawa kerumah sakit terdekat untuk mendapatkan pertolongan pertama. Namun sering kali supir ambulance tidak mengetahui jalur mana yang akan dilalui agar dapat sampai ke lokasi pasien gawat darurat dalam kondisi seperti ini dibutuhkan sebuah sistem berupa pencarian jalur terpendek agar dapat mempermudah melakukan penjemputan pasien gawat darurat sehingga korban tersebut dapat ditangani secepat mungkin.

Ambulance berperan penting dalam penanganan pasien gawat darurat yang membutuhkan kecepatan dalam penanganan pasien. Namun demikian, karena kondisi lalu lintas dijalan raya ambulance seringkali mengalami keterlambatan kedatangan maupun keterlambatan dalam membawa pasien kerumah sakit. Algoritma Bellmand Ford dapat menemukan rute terpendek dari titik awal (rumah sakit) sampai ke titik tujuan dengan cepat, yang merupakan algoritma pencarian rute terpendek dengan memperhitungkan semua kemungkinan rute. dengan adanya teknologi $L B S$ (location based service) yang merupakan bagian dari teknologi komunikasi berbasiskan pada lokasi geografis, teknologi ini akan memberikan informasi sesuai dengan lokasi keberadaan kita. Dengan memanfaatkan teknologi GPS (Global Positioning system) yang dapat mendeteksi keberadaan pengguna dan $L B S$ dapat memberikan nilai tambah layanan dalam membangun sebuah aplikasi pencarian rute terdekat dimana dengan teknologi ini akan memberikan informasi
p-ISSN : 2527-4856, e-ISSN : 2614-5413

https://journal.uniku.ac.id/index.php/buffer

kondisi lalu lintas, informasi rute terdekat sesuai dengan lokasi keberadaan kita.

\section{METODE PENELITIAN}

\subsection{Metode Penelitian}

Metode penelitian yang di pakai pada pengembangan aplikasi ini adalah dengan menggunakan metode Rational Unified Process (RUP), metode ini penulis gunakan dikarnanakan dikarnakan konsep object oriented yang cocok dengan konsep aplikasi yang akan dibangun, berikut 4 fase tahapan :

1) Inception

Tahap ini lebih pada memodelkan proses bisnis yang di butuhkan dan mendefinisikan kebutuhan akan sistem yang akan di buat (requirements).

2) Elaboration (perluasan dan perencanaan)

Tahap ini lebih di fokuskan pada perencanaan arsitektur sistem. Tahap ini juga mendeteksi apakah arsitektur sistem yang diinginkan dapat dibuat atau tidak. Tahap ini lebih pada analisis dan desain sistem pembuatan alur sistem, pemodelan diagram UML (Business Use Case, Use case diagram, Diagram Activity, dan Class Diagram), arsitektur sistem serta implementasi sistem yang fokus pada purwarupa system (prototype).

3) Construction (Konstruksi)

Tahap ini lebih pada pengebangan komponen dan fiturfitur system dan implementasi dari hasil desain serta pengujian sistem yang fokus pada implementasi perangkat lunak pada kode program. Dalam rancangan aplikasi disini menggunakan QR-Code yang di terapkan dengan menggunakan android. 
4) Transition

Tahap ini lebih pada deployment atau instalasi sistem agar dapat dimengerti oleh pengguna. Tahap ini menghasilkan produk perangkat lunak dan fokus pada pelatihan pengguna, pemeliharaan dan pengujian sistem apakah sudah memenuhi harapan.

2.2 Analisis Kebutuhan

Analisis kebutuhan sistem menggambarkan kebutuhan sistem yang di perlukan untuk menjalankan aplikasi yang akan dibangun. Adapun kebutuhan sistem untuk aplikasi mobile payment, yang akan dibuat meliputi kebutuhan sistem perangkat keras dan kebutuhan perangkat lunak. Analisis kebutuhan sistem bertujuan agar aplikasi yang akan dibangun dapat digunakan sesuai dengan kebutuhan nantinya.

Analisis Kebutuhan Perangkat Keras antara lain :

1. Kebutuhan Perangkat Keras (Hardware) Perangkat keras yang digunakan untuk membangun aplikasi ini terdapat pada tabel 1 berikut :

Tabel 1 Spesifikasi Perangkat Keras

\begin{tabular}{|l|l|}
\hline Komponen & Spesifikasi yang dipakai \\
\hline Processor & Intel Core i3 \\
\hline RAM & 4 GB DDR3 \\
\hline Display & Resolusi 1400 x 780 pixel \\
\hline Harddisk & 160 GB \\
\hline
\end{tabular}

2. Kebutuhan Perankat Lunak (Software)

Selain kebutuhan perangkat keras dalam pembangunan login validasi praktikum, diperlukan juga beberapa perangkat lunak untuk proses desain dan coding, perangkat lunak yang akan digunakan seperti pada tabel 2 dibawah ini :
p-ISSN : 2527-4856, e-ISSN : 2614-5413

https://journal.uniku.ac.id/index.php/buffer

Tabel 2 Spesifikasi Perangkat Lunak

\begin{tabular}{|l|l|}
\hline Komponen & Nama Perangkat Lunak \\
\hline $\begin{array}{l}\text { Sistem } \\
\text { Operasi }\end{array}$ & Windows 64bit \\
\hline & $\begin{array}{l}\text { Rational Rose 2002, } \\
\text { Notepad++, Visio 2010, } \\
\text { Android Studio, Xampp. }\end{array}$ \\
Software & .
\end{tabular}

3. HASIL DAN PEMBAHASAN

3.1 Desain Sistem

1) Usecase Diagram Aplikasi pencarian rute

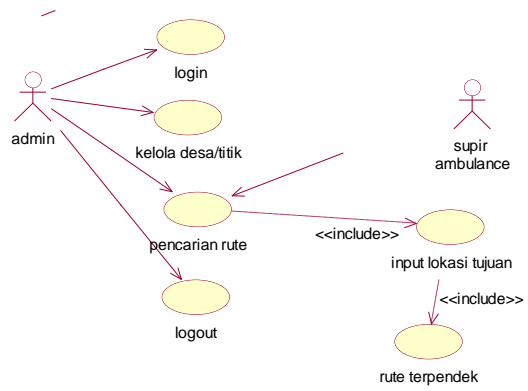

Gambar 1 Use Case Diagram Aplikasi Pencarian rute

Pada usecase terdapat 6 usecase utama antara lain Login, kelola desa/titik, pencarian rute, input lokasi tujuan, rute terpendek logout

2) Sequence Diagram

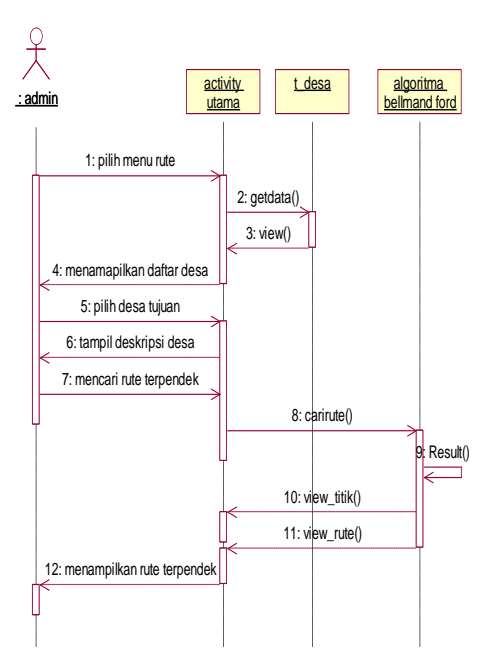

Gambar 2 Sequence Diagram Kelola desa/titik 
JURNAL BUFFER INFORMATIKA

Volume 5 Nomor 2, Oktober 2019

3) Peracangan Database

Terdapat 1 tabel utama pada aplikasi ini antara lain tabel pelanggan.

Tabel 3 Tabel Pelanggan

\begin{tabular}{|l|l|l|}
\hline Nama (Field) & Tipe (panjang) & \multicolumn{1}{|c|}{ Key } \\
\hline Id_desa & Int (3) & $\begin{array}{l}\text { Primary } \\
\text { key }\end{array}$ \\
\hline Nama desa & Varchar(35) & - \\
\hline alamat & Varchar(30) & - \\
\hline Deskripsi & Text & - \\
\hline longtitude & Double & - \\
\hline Langtitude & Double & - \\
\hline
\end{tabular}

3.2 Implementasi Algoritma Bellmand Ford

Algoritma Bellman-Ford yang ditemukan oleh Richard E. Bellman, seorang ahli matematika yang terlahir di New York 1920. Algoritma Bellman-Ford menghitung jarak terpendek (dari satu sumber) pada sebuah graf berbobot. Maksudnya dari satu sumber ialah bahwa ia menghitung semua jarak terpendek yang berawal dari satu titik node. (Bayu Aditya Pradhana, 2006)

Algoritma Belman Ford merupakan algoritma untuk mencari shortest path, Algoritma ini mencari single-source dari suatu vertek tunggal shortest path, dilakukan secara increment mencari shortest path dari s ke vertek yang lain di $G$ dan selalu memilih suatu edge ke suatu vertek tertutup yang terdekat, dengan kompleksitas dengan cara menghitung jarak tercepat (dari satu sumber) pada sebuah digraph berbobot. Maksudnya dari satu sumber ialah bahwa ia menghitung semua jarak terpendek yang berawal dari satu titik node. Algoritma Bellman Ford dapat lebih bagus mencari hal yang sama.

Mengatakan Algoritma Bellman Ford akan benar hanya jika graph tidak terdapat cycle dengan bobot negatif yang dicapai. Algoritma Belman Ford adalah Single Source Shortest Path yaitu jarak terpendek dari setiap vertex tunggal pada graph berarah yang berbobot menuju vertex
p-ISSN : 2527-4856, e-ISSN : 2614-5413

https://journal.uniku.ac.id/index.php/buffer

tujuan tertentu. Disebut single source karena membutuhkan satu titik sebagai awal pencarian. Algoritma lain yang termasuk single source shortest path ini adalah Algoritma Dijkstra.

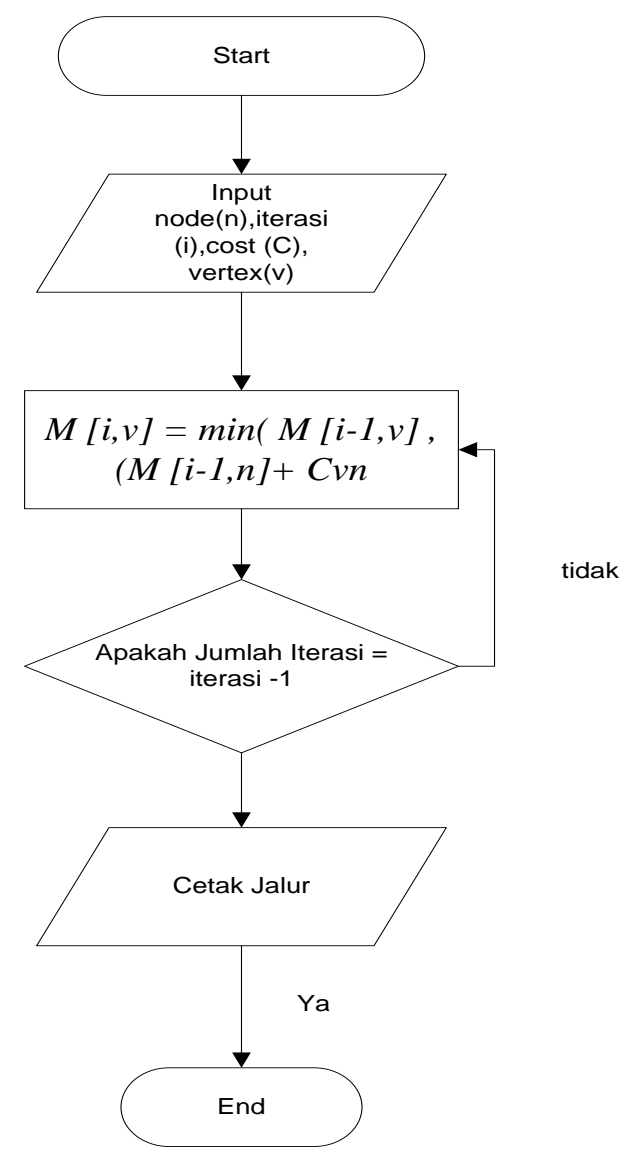

Gambar 3 Flowchart proses algoritma Bellman Ford

3.3 Interface Desain antarmuka

Setelah melakukan perancangan, tahap selanjutnya adalah implementasi. Yaitu tahap penerapan hasil perancangan yang prosesnya telah diuraikan pada bab III. Implementasi yang dilakukan antara lain adalah pembuatan kode program untuk membangun komponen-komponen pokok sebuah sistem berdasarkan desain yang sudah dibuat, menerapkan hasil perancangan interface, dan sebagainya.

Berdasarkan rancangan interface yang telah ada pada bab III 
JURNAL BUFFER INFORMATIKA

Volume 5 Nomor 2, Oktober 2019

sebelumnya maka dihasilkan tampilan sebagai berikut:

- Halaman Login WEB

Halaman login merupakan halaman yang digunakan saat user akan masuk ke dalam sistem. Berikut tampilan halaman login dapat dilihat pada gambar 4 .

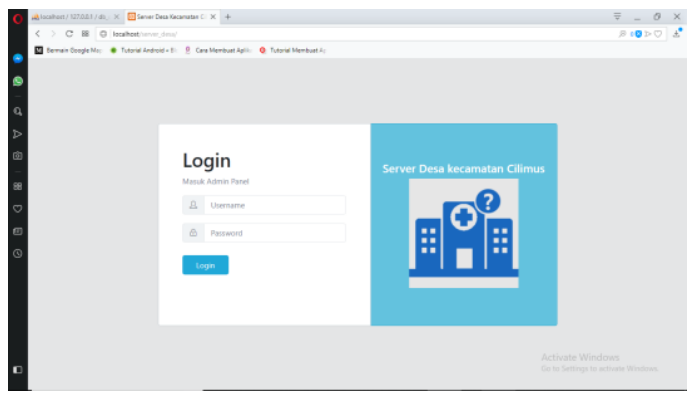

Gambar 4 Halaman Login WEB

Pada halaman login, user memasukan username dan password yang telah didaftarkan sebelumnya. Kemudian sistem akan melakukan pengecekan ke server. Jika sesuai maka sistem akan menampilkan halaman utama dan jika username atau password tidak sesuai maka sistem akan menampilkan pesan username atau password salah.

- Halaman Daftar desa/titik

Halaman daftar desa/titik merupakan halaman yang digunakan untuk menampilkan data tiik tujuan ke dalam sistem. Berikut tampilan halaman daftar desa/titik pada gambar 5

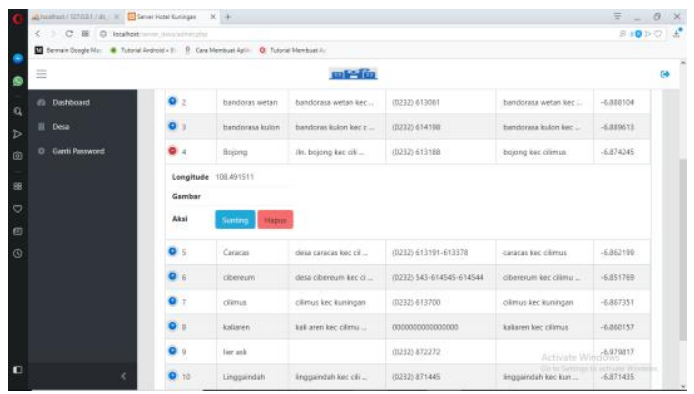

Gambar 5 Halaman daftar desa/titik
p-ISSN : 2527-4856, e-ISSN : 2614-5413

https://journal.uniku.ac.id/index.php/buffer

- Halaman main menu

Halaman main menu aplikasi yang telah dibuat oleh pngguna gambar 6

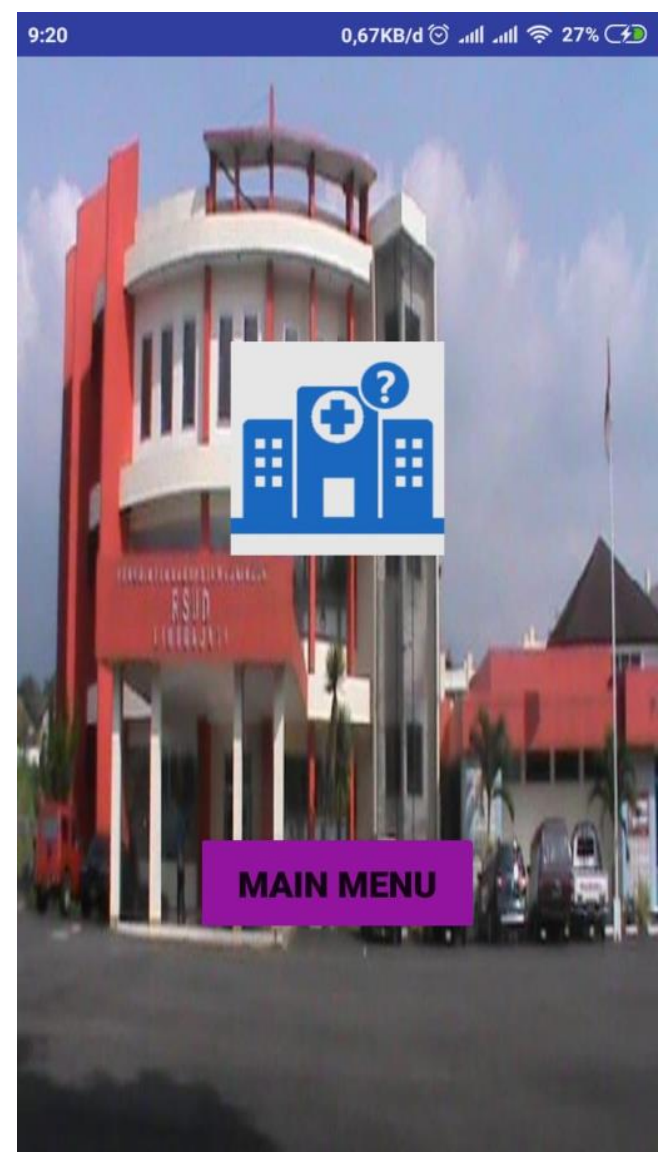

Gambar 6 Halaman Menu Pelanggan

- Halaman menu utama aplikasi

Halaman Menu utama aplikasi merupakan tampilan menu utama aplikasi dimana terdapat pilihan, menu rute, peta lokasi, tentang dan keluar aplikasi gambar 7 . 


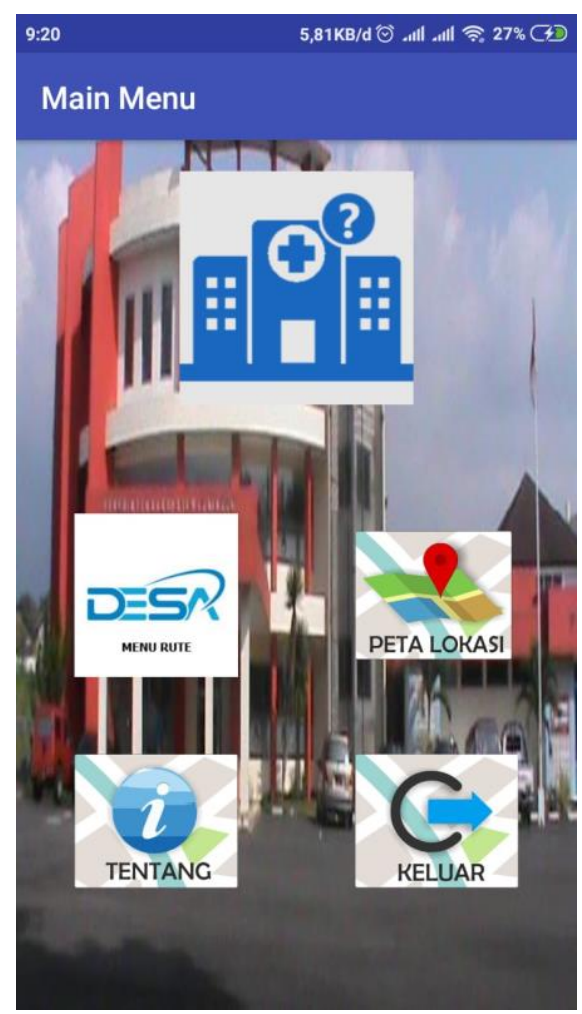

Gambar 7 Halaman Menu utama aplikasi

- Halaman daftar titik tujuan desa/titik

Halaman daftar titik tujuan desa/titik merupakan menu rute yang akan menampilkan informasi beberapa data data tujuan yang dapat dipilih oleh admin/user dilihat pada gambar 8

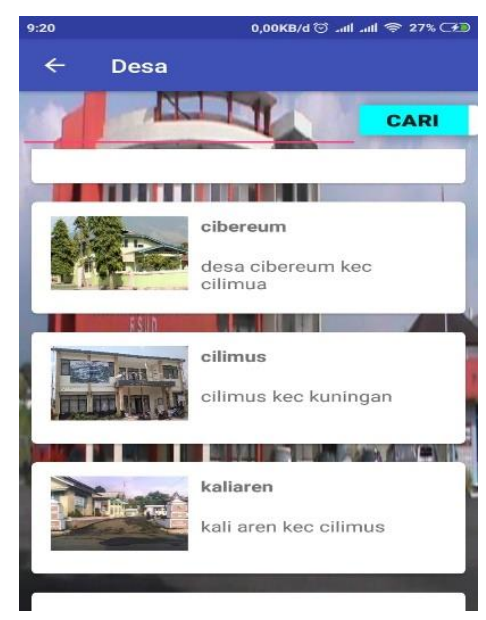

Gambar 8 Halaman daftar titik/desa
p-ISSN : 2527-4856, e-ISSN : 2614-5413

https://journal.uniku.ac.id/index.php/buffer

- Halaman Rute terpendek

Halaman tampil rute terpendek, menampilkan rute terpendek yang telah dipilih sebelumnya, sehingga menampilkan rute terpendek dimap Berikut tampilan halaman rute terpendek dapat dilihat pada gambar 9 .

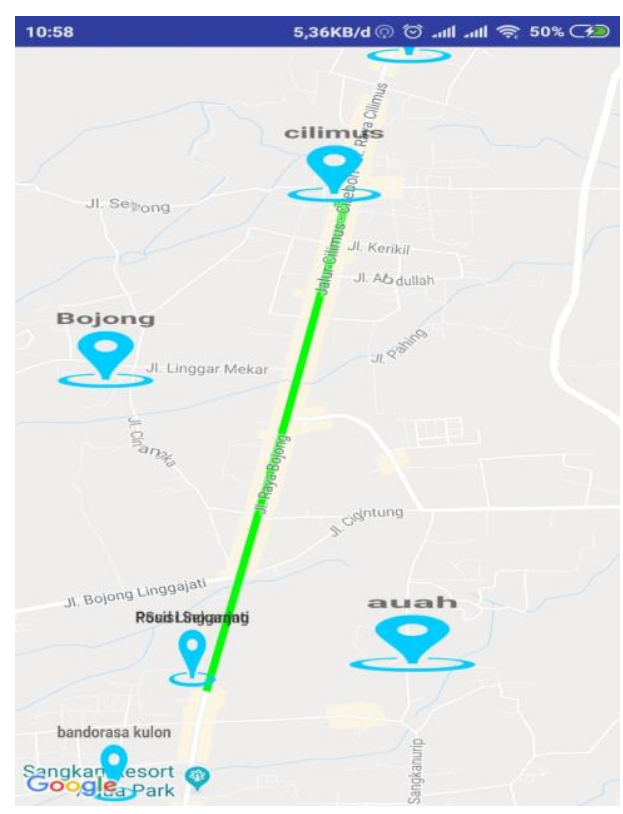

Gambar 9 Halaman Rute Terpendek

\section{KESIMPULAN}

Berdasarkan uraian dan hasil pembahasan dari bab 1 sampai bab 4 dan pembangunan aplikasi Implementasi Algortima Bellmand Ford Untuk Menjemput Pasien Menggunakan Mobil Ambulance Dengan Location Based Service (LBS) Berbasis Android (Studi Kasus: RSUD Linggajati), dapat diambil kesimpulan sebagai berikut :

1. Memudahkan supir ambulance untuk menemukan jalur tercepat ke alamat yang dituju

2. Algoritma Bellmand Ford dapat menemukan rute terpendek dari titik awal (rumah sakit) sampai ke titik tujuan dengan cepat

\section{SARAN}

Dengan segala kekurangan yang dimiliki, penulis mengakui aplikasi yang 
dibangun masih banyak memiliki kekurangan dan untuk pengembangan kedepannya, ada beberapa hal yang disarankan yaitu :

1. Membuat aplikasi dijadikan sebuah kesatuan sistem yang utuh yang terintegrasi. Seperti pemesan mobil ambulance dapat dilakukan oleh sistem aplikasi yang telah dibuat

2. Untuk kedepannya, si pasien dapat melakukan pemesanan lewat aplikasi yang akan dibuat

\section{DAFTAR PUSTAKA}

[1] Al Bahra Bin Ladjamudin. 2006. Rekayasa Perangkat Lunak. Graha Ilmu.

[2] Bayu Aditya Pradhana, 2006' Studi dan Implementasi Persoalan Lintasan Terpendek Suatu Graf Dengan Algoritma Dijkstra dan Algoritma Bellman Ford

[3] Corment, Thomas H, Leiserson, Charles E, Rivest, Ronald L pada buku algoritma: MIT Press 1994

[4] Hartono, Jogiyanto. 1999. Analisis Dan Disain Sistem Informasi: pendekatan terstruktur teori dan praktek aplikasi bisnis

[5] Guntur Setiawan, Implementasi Dalam Birokrasi Pembangunan, 2004.hal.39.

[6] King, P. W. (2009). Climbing Maslow's Pyramid : Choosing Your Own Path Through Life. Leicester, United Kingdom: Troubador Publishing Ltd.

[7] Hengky W. Pramana, (2012). Aplikasi Inventory Berbasis Access 2003.PT. Elex Media Komputindo, Jakarta.
p-ISSN : 2527-4856, e-ISSN : 2614-5413

https://journal.uniku.ac.id/index.php/buffer

[8] Guntur Setiawan (2014).

Implementasi Dalam Birokrasi

Pembangunan. Bandung:Remaja

Rosdakarya.

[9] Nugroho, Adi. 2005. Rational Rose untuk Pemodelan Berorientasi Obyek. Bandung: Informatika.

[10] Hasan Iskandar, (2012). PTS. Upaya Meningkatkan Kompetensi Guru MIPA dalam Menyusun RPP melalui Supervisi Akademik dsi SMPN 15 Kota Gorontalo, Gorontalo.

[11] Wididi, joko.2011. Analisis kebijakan publik: Konsep dan Aplikasi Analisis Proses Kebijakan Publik Malang: Bayu Media.

[12] Taryana Suryana, 2007. Metode RUP (Rational Unfied Process) .STMIK LIKMI. Bandung

[13] Indiahono, Dwiyanto. 2009. Kebijakan Publik Berbasis Dynamic Policy Analisys. Gava Media: Yogyakarta

[14] Kadir, Abdul. (2013). Buku Pintar Programmer Pemula PHP. Yogyakarta: Penerbit MediaKom.

[15] Krismiaji, (2010). Sistem Informasi Akuntansi edisi ketiga. Yogyakarta: Unit Penerbit dan Percetakan Sekolah Tinggi Ilmu YKPN.

[16] Nugroho, Adi (2009). Rational Rose Untuk Pemodelan Berorientasi Objek. Bandung : Informatika.

[17] Wahana Komputer dan Andi. 2001. Buku Pintar Penanganan Jaringan Komputer. Wahana Komputer dan Andi. Semarang, Yogyakarta. 
JURNAL BUFFER INFORMATIKA

Volume 5 Nomor 2, Oktober 2019

[18] Rosa A. S., M. Shalahudin. (2013). Rekayasa Perangkat

Lunak Terstruktur dan Berorientasi Objek. Bandung : Informatika
p-ISSN : 2527-4856, e-ISSN : 2614-5413

https://journal.uniku.ac.id/index.php/buffer

[19] Satyaputra, Alfa \& Aritonang, Eva Maulina. (2016). Let's Build Your Android Apps with Android Studio. Jakarta: PT Elex Media Komputindo. 